\title{
INHIBITION OF GASTRIC SECRETION BY A WATER EXTRACT FROM BACCHARIS TRIPTERA, MART
}

\author{
MARIA T. GAMBERINI; L. A. SKORUPA * CADEN SOUCCAR \& ANTONIO J. LAPA ${ }^{+}$
}

Escola Paulista de Medicina Departamento de Farmacologia INFAR, Setor de Produtos Naturais, Rua Três de Maio 100, São Paulo, SP, Brasil *CENARGEM, EMBRAPA, 70000 Brası́lia, DF, Brasil

Baccharis triptera Mart, is a widespread Compositae used in Brazilian folk medicine to treat gastrointestinal disturbances, rheumatic disease, mild fever, diabetes and as an anti-helminthic. Water extract of small branches of the plant $(W E)$ administered to mice and rats 10.1 to $2 \mathrm{~g} / \mathrm{kg}$, p.o.) did not alter spontaneous motor activity, sleeping time induced by barbiturates or the tailflick response in mice. The extract decreased by $40 \%$ the number of writhings induced by $0.8 \%$ acetic acid, i.p., but did not influence paw edema induced by carrageenan or dextran in rats. WE $(2 \mathrm{~g} / \mathrm{kg}$, p.o.) decreased the intestinal transit of charcoal in mice by $20 \%$. Gastric secretion in pylorus ligated rats was reduced after treatment with $W E(1$ and $2 \mathrm{~g} / \mathrm{kg}$, i.p. or intraduodenal) and the gastric $\mathrm{pH}$ was raised. The extract $(1 \mathrm{~g} / \mathrm{kg}, \mathrm{p.o}$.$) prevented gastric ulcers induced in rats by$ immobilization at $4^{\circ} \mathrm{C}$, but not those induced by indomethacin $\left(10 \mathrm{mg} / \mathrm{kg}, \mathrm{s}_{\mathrm{c}} \mathrm{c}\right.$.). The results indicate that WE may relieve gastrointestinal disorders by reducing acid secretion and gastrointestinal hiperactivity. Neither analgesic nor anti-inflammatory activities were detectable.

Key words: Baccharis triptera - gastric secretion - medicinal plant

Baccharis triptera (trimera) Mart, family Compositae, is a small plant widely distributed in Brazil, popularly known as "Carqueja", "Carqueja amargosa", "Quina de Condaime" and "Vassoura". Medicinal teas prepared with the flowery plant are usually employed in folk medicine for gastrointestinal disturbances, rheumatic disease, mild fever, diabetes and as an anti-helminthic (Coimbra, 1958; Pio Corrêa, 1926).

The present work aimed to study the pharmacological activities of the water extract of B. triptera Mart mainly its reputed gastrointestinal, analgesic and anti-inflammatory properties.

\section{MATERIALS AND METHODS}

The plant was collected in Brasilia, DF, in a plantation grown at EMBRAPA/Ministry of Agriculture. Small branches of the plant were extracted with water $\left(5 \%, 73^{\circ} \mathrm{C}\right)$ for $30 \mathrm{~min}$.

Research financial support from CAPES, CNPq and CEME.

M. T. Gamberini was a recipient of fellowship from FAPESP.

+ Corresponding author.
The extract (WE) was then concentrated and freeze-dried. Biological tests were done using rats (200-250 g body weight) and mice (30$40 \mathrm{~g}$ ) of either sex.

Pharmacological tests in vivo were: general pharmacological screening (Malone, 1977); sleeping time induced by sodium pentobarbital $(50 \mathrm{mg} / \mathrm{kg}$, i.p.) in mice (Carlini \& Burgos, 1979); analgesic activity was measured in mice by the latency of response to immersion of the tail in a water bath at $55^{\circ} \mathrm{C}$ (Janssen et al., 1963), and writhing induced by $0.8 \%$ acetic acid $(0.1 \mathrm{ml} / 10 \mathrm{~g}$, i.p.) in mice (Koster et al., 1959); anti-inflammatory activity was tested by the method of paw edema induced by either $1 \%$ carrageenan or $1 \%$ dextran (Winter et al., 1962). The gastrointestinal activity of WE was evaluated by determination of: the gastrointestinal transit of charcoal 10\% (Stickney \& Northup, 1959); the changes of gastric secretion in pylorus ligated rats (volume, $\mathrm{pH}$ and total acidity) (Vissher et al., 1954; Domer, 1971); protection against acute gastric ulcer induced by immobilization at $4^{\circ} \mathrm{C}$ (Parè, $1977)$ or by indomethacin $(10 \mathrm{mg} / \mathrm{kg}$, s.c.) (Carlini, 1988) and by evaluation of the degree of gastric ulceration. The index of ulceration was scored as follows: loss of mucosal foldings, 
mucosal discolouration, edema or hemorrhage (score 1 each); less than 10 petechiae (score 2 ), more than 10 petechiae (score 3 ); ulcers $/ \mathrm{cm}^{2}$ less than $1 \mathrm{~mm}$ (score number of ulcers $\times 2$ ); ulcers more than $1 \mathrm{~mm} / \mathrm{cm}^{2}$ (score number $x$ 3); perforated ulcers (score number $x 4$ ).

In vitro preparations of rat jejunum and vas deferens at $30^{\circ} \mathrm{C}$ were used to assay the extract either alone or in presence of acetylcholine or norepinephrine. Constitution of the nutritive solutions where as follows ( $\mathrm{mM}$ ): $\mathrm{NaCl} 135.0, \mathrm{KCl} 5.0, \mathrm{MgCl}_{2} 1.0, \mathrm{CaCl}_{2} 1.8$, $\mathrm{NaHCO}_{3} 15.0, \mathrm{NaH}_{2} \mathrm{PO}_{4} 1.0$ and glucose 11.1 gassed with $95 \% \mathrm{O}_{2}-5 \% \mathrm{CO}_{2}$ for jejunum preparations, and $\mathrm{NaCl} 64.0, \mathrm{KCl} 81.7$, $\mathrm{NaH}_{2} \mathrm{PO}_{4} 0.36, \mathrm{NaHCO}_{3} 15.0$ and glucose 5.5 gassed with air for vas deferens preparations.

Results are given as means \pm s.e. mean or s.d. when indicated. Differences between control and treated groups were determined by the Student " $t$ " test at $\mathrm{P}<0.05$.

\section{RESULTS}

WE $(0.01$ to $2 \mathrm{~g} / \mathrm{kg}$, i.p. $)$ in mice and rats induced writhings, ptosis and reduced spontaneous motor activity in a dose-dependent fashion. Oral administration was ineffective. The sleeping time $(76.5 \pm 4.2 \mathrm{~min})$ was not significantly altered by previous administration (30 $\mathrm{min}$ ) of WE 0.5 and $1 \mathrm{~g} / \mathrm{kg}$, p.o. $(71.8 \pm 4.4$ $\mathrm{min}$ and $70.5 \pm 4.2 \mathrm{~min}$, respectively).

Similarly, the tail-flick latency in control mice $(2.2 \pm 0.1 \mathrm{~s})$ did not differ from that obtained following treatment with WE $(2 \mathrm{~g} / \mathrm{kg}$, p.o.), assessed $30(2.1 \pm 0.3 \mathrm{~s})$ and $120(2.1 \pm$ $0.2 \mathrm{~s})$ min after administration.

Writhings in control animals $(62.8 \pm 5.5$ writhings $/ 30 \mathrm{~min}$ ) were reduced in mice pretreated with WE (1 and $2 \mathrm{~g} / \mathrm{kg}$, p.o.) by $30 \%$ and $40 \%$ of control. Administration of equal doses of WE to rats however, did not inhibit hind-paw edema induced by either carrageenan or dextran.

In control mice $91.1 \pm 3.5 \%$ of the small bowel length was filled with charcoal after 45 min of gastric administration of the marker. Pretreatment (30 min) with WE $(2 \mathrm{~g} / \mathrm{kg}$, p.o.) reduced the intestinal transit of charcoal by $20 \%$ of control.
In isolated jejunum preparations incubation of WE $(0.5-8 \mathrm{mg} / \mathrm{ml})$ caused relaxation of the smooth musculature, which was dependent on the dosis and on the previous tonus of the organ. WE $(0.5$ and $1 \mathrm{mg} / \mathrm{ml})$ did not alter the maximal contractile response induced by acetylcholine (ACh), nor did it shift the doseresponse curve to the agonist. In rat vas deferens preparations, WE $(1,5$ and $10 \mathrm{mg} / \mathrm{ml})$ reduced the maximal contraction induced by either $\mathrm{ACh}$ ( $40 \%$ to $60 \%$ ) or noradrenaline (30\% to $90 \%$ ) without shifting the dose-response curves to either agonist.

Gastric secretion collected $4 \mathrm{~h}$ after pylorus ligature in rats was reduced by $93 \%$ after i.p. treatment and by $85 \%$ after intraduodenal administration of WE $(1 \mathrm{~g} / \mathrm{kg})$. At the same time either treatment decreased total acid secretion by $94 \%$ and $49 \%$ and raised the gastric $\mathrm{pH}$ to 4.4 and 5.5, respectively. Ranitidine (50 $\mathrm{mg} / \mathrm{kg}$ ) used as a positive control also reduced the volume of gastric secretion and raised its $\mathrm{pH}$ (Table).

\section{TABLE}

Effect of intraperitoneal (IP) or in traduodenal (D) administration of the water extract (WE) of Baccharis triptera Mart on the gastric secretion of rats

\begin{tabular}{lcccr}
\hline Treatment & & $\begin{array}{c}\text { Volume } \\
(\mathrm{ml})\end{array}$ & $\mathrm{pH}$ & \multicolumn{1}{c}{$\begin{array}{c}\text { Gastric } \\
\text { acidity } \\
(\mathrm{mEq} / \mathrm{l})\end{array}$} \\
\hline Control & IP & $4.1 \pm 2.6$ & $2.5 \pm 1.3$ & $49.4 \pm 38.3$ \\
& $\mathrm{D}$ & $4.7 \pm 1.7$ & $2.0 \pm 0.6$ & $41.7 \pm 21.4$ \\
$\mathrm{WE}(1 \mathrm{~g} / \mathrm{kg})$ & IP & $0.3 \pm 0.1^{a}$ & $4.4 \pm 1.6$ & $2.8 \pm 1.9^{a}$ \\
& $\mathrm{D}$ & $0.7 \pm 0.1^{a}$ & $5.5 \pm 2.3^{a}$ & $21.1 \pm 20.9$ \\
Ranitidine & IP & $1.9 \pm 1.2$ & $6.8 \pm 0.7^{a}$ & $7.7 \pm 7.6^{a}$ \\
$(50 \mathrm{mg} / \mathrm{kg})$ & $\mathrm{D}$ & $2.3 \pm 1.8$ & $4.9 \pm 1.9^{a}$ & $11.1 \pm 9.9^{a}$ \\
\hline
\end{tabular}

Secretion was collected during $4 \mathrm{~h}$ after pylorus ligation.

Results are means \pm s.d. of $5-6$ animals.

$a$ : different from control $(\mathrm{P}<0.05)$.

Pretreatment of rats with WE (1 and $2 \mathrm{~g} / \mathrm{kg}$, p.o.) reduced the ulceration index (by $76 \%$ and $84 \%$ ) as well as, the number of ulcers (by $40 \%$ and $60 \%$ ) induced by immobilization at $4{ }^{\circ} \mathrm{C}$ for $2 \mathrm{~h}$ (Fig.). At equal doses however, WE was ineffective in protecting against gastric ulcers induced by indomethacin. 


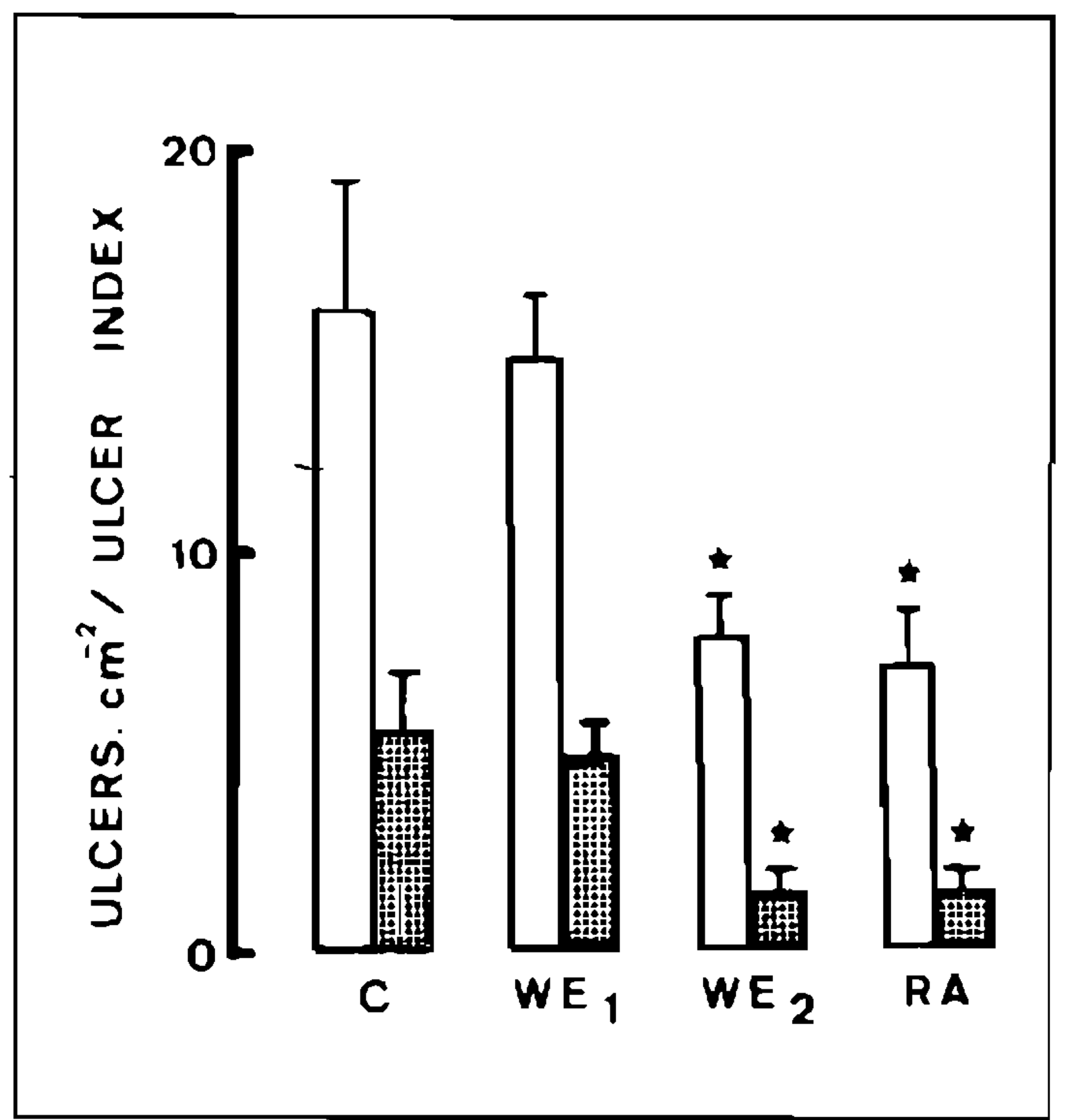

Effect of administration of the water extract of Baccharis triptera Mart on gastric ulceration in rats. Ulcers. $\mathrm{cm}^{-2}$ (dark columns) and index of ulcerogenesis (white columns) in rats immobilized for $2 \mathrm{~h}$ at $4^{\circ} \mathrm{C}$. Control $(C)$; rats treated orally $1 \mathrm{~h}$ before with the water extract of $B$, triptera Mart (WE1 - $1 \mathrm{~g} / \mathrm{kg}$; WE2 $-2 \mathrm{~g} / \mathrm{kg}$ ), and rats treated with ranitidine (RA - 50 $\mathrm{mg} / \mathrm{kg}$ ). Columns and vertical bars are means \pm s.e. mean of 5 animals each. $\downarrow$ - indicates difference from control $(P<0.05)$.

\section{DISCUSSION}

The pharmacological effects of the water extract of $B$. triptera Mart on the intestinal transit and in vitro experiments justify its popular use as antidiarrhoeal and antispasmodic medicine. This antispasmodic activity is probably unrelated to an atropinic mechanism.

The extract did not inhibit the responses of mice on the tail-flick test, nor did it decrease the edema induced by either carrageenan or dextran in rats. Inhibition of writhing induced by acetic acid in mice may be due to the antispasmodic activity of the extract described above. Those data thus do not support the popular indication of $B$. triptera as an analgesic/ anti-inflammatory agent.

On the other hand, the strong inhibition of gastric secretion produced by the plant extract is a good indication of the anti-acid, antidyspeptic and anti-ulcer activities referred popularly. The data so far obtained do not indicate however, which specific mechanism(s) is (are) responsible for those actions.

\section{REFERENCES}

CARLINI, E. A., 1988. Estudo da açāo antiúlcera gástrica de plantas brasileiras: Maytenus ilicifolia (Espinheira Santa) e outras. Brasilia, CEME/AFlP, $87 \mathrm{p}$.

CARLINI, E. A. \& BURGOS, V., 1979. Screening farmacológico de ansiolíticos: metodologia laboratorial e comparação entre o diazepan e cloro. benzapan. Rev. Assoc. Bras. Psiq. Säo Paulo, I: 25-31.

COIMBRA, R., 1958. Notas de fitoterapia. Catálogo dos dados principais sobre plantas utilizadas em Medicina e Farmácia. Ed. revista por Prof. Dr. E. D. Silva. Rio de Janeiro, 427 p.

DOMER, F. R., 1971. Animal experiments in pharmacological analysis. Charles $\mathrm{C}$. Thomas Publisher, 669 p.

JANSSEN, P. A. J.; NIEMEGGEERS, C. J. E., \& DONY, J. G. H., 1963. The inhibitory effect of Fentanyl and other morphine-like analgesics on the warm water induced tail withdrawal reflex in rats. Arzneim-Forsch. Drug. Res., 13: 502-507.

KOSTER, R.; ANDERSON, M. \& BEER, E. J., 1959. Acetic acid for analgesic screening. Fed. Proc., $18 ; 412$.

PARE, W. P., 1977. Body temperature and the active stress ulcer in the rat. Physiol. Behav., 18: 219223.

PIO CORRẼA, M., 1926. Dicionário das plantas úteis do Brasil e das exóticas cultivadas. Ministério da Agricultura. Instituto de Desenvolvimento Florestal., Imprensa Nacional, Vol. II p. 74.

STICKNEY, J. C. \& NORTHUP, D. W., 1959. Effect of gastric emptying upon propulsive motility of small intestine in rat. Proc. Soc. Exp. Biol. Med., $101: 582-583$ 